\title{
ULOGA PREVOĐENJA U NASTAVI JEZIKA STRUKE
}

U nastavi jezika struke na tercijarnom nivou uloga prevođenja znatno se razlikuje od prevođenja kao jezičke veštine koju studenti stiču na filološkim studijama. Budući da je strani jezik studentima nefilološke orijentacije pre svega sredstvo pomoću kojeg dolaze do saznanja iz svoje disciplinarne oblasti, veoma je važno da se uloga prevođenja u ovom tipu nastave stranog jezika jasno odredi u skladu sa jezičkim i stručnim potrebama studenata, odnosno budućih stručnjaka koji u okviru studijskih programa izučavaju i strani jezik za posebne namene. U radu se razmatra uloga i značaj prevođenja kao metodološkog postupka provere razumevanja pročitanog na nižim nivoima učenja stranog jezika, u ovom slučaju italijanskog.

Za potrebe ovog eksplorativnog kvantitativno-kvalitativnog istraživanja analizirano je 134 prevoda studenata društveno-humanističkog usmerenja koji uče italijanski jezik kao obavezan predmet na prvoj i drugoj godini studija na Filozofskom fakultetu Univerziteta u Beogradu. Rezultati istraživanja pokazuju da je u radu na tekstu struke, što čini okosnicu nastave stranog jezika na nefilološkim fakultetima, prevođenje s ciljem izvlačenja ključnih informacija iz teksta i uvežbavanja globalnog i detaljnog razumevanja korisno i svrsishodno jer razvija kod studenata svest o jeziku struke, terminološko-leksičkim i diskursnim osobenostima ovog jezičkog varijeteta, kao i metakognitivne i kognitivne strategije učenja i razumevanja pročitanog.

Ključne reči: prevođenje, jezik struke, univerzitetska nastava, razumevanje pročitanog, italijanski jezik

\section{Uvod}

Uloga prevođenja u okviru nastave stranih jezika menjala se kroz dugu istoriju glotodidaktike. Ova jezička veština usko je vezana za jedan od najpoznatijih metoda učenja stranih jezika - gramatičko-prevodni metod. Raširen tokom čitavog XIX veka, a zastupljen još uvek u značajnoj meri i u prvoj polovini $\mathrm{XX}$, on u praksi svoje pristalice nalazi ponegde $\mathrm{i}$

* ddjorovi@f.bg.ac.rs 
danas. Po uzoru na učenje latinskog i grčkog jezika, ovaj sintetičko-deduktivni metod ponikao je na uverenju da je učenje stranih jezika otkrivanje i utvrđivanje univerzalne logike klasičnih jezika, te da se nastava stranih jezika zasniva na tome da učenici nauče kako da te univerzalne gramatičke kategorije primene i izraze na novom jeziku koji uče (Vučo, 2009: 198). Učenje jezika imalo je karakter vežbe intelektualnih sposobnosti, a prevod bio način da se eksplicitno predočeni gramatički i leksički elementi upotrebe u prevođenju tekstova i bolje memorišu, što je za posledicu imalo dobru pismenu upotrebu stranog jezika kakvim su pisali veliki autori, a ne onog govornog, svakodnevnog. Prevođenje je tu služilo kao dokaz ovladavanja stranim jezikom (Bausch, 1989: 227). Već s pojavom bihevioristički utemeljenih audio-oralnih metoda prevođenje će postajati sve više ozloglašeno zbog negativnih interferencija maternjeg jezika, a kad se s komunikativnim metodom akcenat premesti na sticanje komunikativne kompetencije prevođenje će biti potisnuto u sasvim sporedan plan.

Status prevođenja u nastavi stranih jezika nije razjašnjen do kraja ni danas. Iako se mogu naći potvrde da vežbe prevođenja mogu biti korisne učenicima stranih jezika, ukoliko se koriste promišljeno i selektivno i uklope u savremene didaktičke tendencije okrenute ka učeniku i njegovim komunikativnim potrebama, ni u Zajedničkom evropskom referentnom okviru za žive jezike prevođenje nije detaljnije tretirano. Naime, pominje se kao jedna od aktivnosti medijacije, ali u deskriptorima koji opisuju nivoe vladanja jezikom ova veština nije uopšte zastupljena. Razlog za to neki nalaze u neprimerenosti ove kompetencije kao parametra, te u internacionalnom karakteru certifikacije jezičkih sposobnosti kojoj je Zajednički okvir prevashodno namenjen.

Uprkos svemu gorenavedenom, svako ko je učio neki strani jezik zna da se prevođenje, na ovaj ili onaj način, ne može u potpunosti isključiti iz procesa učenja. Mnogi glotodidaktičari, ali i kognitivni lingvisti i psiholingvisti, istču da u bilo kom spontanom učenju stranog jezika govornik neminovno pribegava strategijama poređenja stranog jezika s maternjim, kao i da je besmislen pokušaj potpunog isključenja maternjeg jezika, pa tako i nekih vidova prevođenja, iz učenja stranih jezika (Brown, 1972; Butzkamm 2002). I iz perspektive komunikativne kompetencije i lingvopragmatike, umeće korišćenja jezika, takozvani savoire faire ,upravo označava sposobnost da se u realnim situacijama pojedinac služi jezikom 
na svrsishodan način, što nužno uključuje i veštinu prevođenja koja razvija određenu metalingvističku i kontrastivnu svest neophodnu za funkcionalno korišćenje dva, tri ili više jezika.

\section{Prevođenje u nastavi opšteg stranog jezika}

Od mnoštva definicija prevođenja koje se mogu naći u literaturi možda je najcitiranija ona koju daje Newmark u svom čuvenom delu $A$ textbook of Translation, gde se prevođenje shvata kao "rendering the meaning of a text into another language in the way that the author intended the text" (Newmark 1988: 5). On dalje razlikuje semantički od komunikativnog prevoda. Semantički prevod, podesan za literarne tekstove, sledi proces autorove misli, ličan je, istančan, prati svaku nijansu u značenju, dok komunikativni prevod, obično nelitrarnih, informativnih tekstova, podrazumeva produkciju tačnog, kontekstualnog značenja originala jezički i sadržinski sasvim prihvatljivu u ciljnom tekstu (Newmark 1988: 46). U zavisnosti od svrhe prevoda, razlikuju se i kompetencije koje treba da ima onaj ko prevodi i sam prevodilački proces, budući da prevođenje može da se shvati kao nauka, veština ili kao umetnost (Newmark, 1988: 189).

Polazeći od teze da je u svakom obliku nastave stranog jezika, bar u određenoj meri, prisutno i prevođenje, razmotrićemo najpre kako se ono uklapa u okvire učenja stranog jezika za opšte namene, uobičajenog u formalnom obrazovnom sistemu na više nivoa, ali i u neformalnom, na kursevima stranih jezika koji su namenjeni širokoj publici. U promišljanju ovog problema oslonićemo se na neke postulate italijanskih glotodidaktičara (Balboni 1998; Freddi 1999). Balboni, naime, ističe da se na početnim nivoima učenja mora dobro voditi računa o tome da se učenje stranog jezika ne poistoveti, odnosno ne svede na traganje za ekvivalentima reči maternjeg jezika u jeziku koji se uči, tj. na puko prevođenje s jednog na drugi jezik (Balboni 1998:83). Prevođenje se obično vezuje za nastavu jezika na višim nivoima, kada se zapravo kroz sve one aktivnosti koje prethode samoj realizaciji prevoda ostvaruje učenje jezika. O prevođenju kao tehnici učenja Balboni govori uvodeći termin problemski prevod (it. traduzione problematica), gde nije nužno cilj da se dođe do nekog gotovog proizvoda koji učenici moraju da realizuju (Balboni, 1998: 82), već je više reč o samom procesu rada na prevodu, promišljanju načina prenošenja elemenata iz jednog u drugi jezik, osvešćivanju teškoća koje se pojavljuju na tom 
putu i razmatranju mogućih rešenja. Balboni smatra da samo na taj način prevođenje može da doprinese tekstualnoj, interlingviistčkoj i interkulturnoj refleksiji o tekstu (Balboni, 1998:84).

Ni Balboni, a ni Freddi nisu pristalice prevođenja kao tehnike za fiksiranje određenih leksičkih i morfosintaksičkih struktura, a Freddi se naročito ne slaže s idejom da se prevod ocenjuje kao provera znanje jezika (Freddi, 1999: 139). S druge strane, obojica se zalažu za korišćenje i shvatanje prevođenja u nastavnom procesu kao još jedne, pete jezičke veštine, pored čitanja, slušanja, razumevanja i govora (Freddi, 1999: 139), odnosno kao međulingvističke veštine (Balboni, 1998: 13). I zaista, kada se jezik uči na primer na filološkim ili prevodilačkiim studijama, razumljivo je da će prevođenje biti veoma značajna i poželjna kompetencija kojom treba da ovlada svaki stručnjak ovog profila. U ovom slučaju, prevođenje ne može biti svedeno prosto na tehniku učenja, već prerasta u jedan od ciljeva učenja stranog jezika za filološki orijentisane učenike. Prevodilačka kompetencija kojoj oni teže podrazumeva s jedne strane sposobnost da se razume značenjski potencijal izvornog teksta na svim jezičkim nivoima, a s druge strane sposobnost preformulacije tog potencija pomoću odgovorajućih jezičkih sredstava za potrebe primaoca ciljnog teksta (Samardžić, 2009: 262). Stvari, međutim, stoje sasvim drugačije kada je reč o prevođenju u okviru nastave jezika struke.

\section{Prevođenje u nastavi stranog jezika struke}

Specifičnost nastave jezika struke leži u načinu na koji se jezik tretira u nastavnom procesu: jezik prestaje da bude cilj, a postaje sredstvo kojim se dolazi do cilja oličenog u sticanju znanja iz neke druge discipline. Od ideje ovladavanja morfosintaksičkim, leksičkim, pragmatičkim nivoom jezika kako bi se na njemu moglo komunicirati, prelazi se na učenje jezika u funkciji struke, kako je Bugarski nazvao ovaj vid učenja jezika (Bugarski 1997:205). Dakle, učenje stranog jezika preusmerava se u skladu sa jezičkim potrebama stručnjaka određene oblasti, kojima je ovladavanje stranim jezikom zaista neophodno za posebne, specifične svrhe. Jezik struke obavlja ulogu posrednika između datog jezika i vanlingvističke stvarnosti oličene u nauci i struci. Naglasak je na posebnoj nameni ovog formalizovanog i kodifikovanog jezičkog varijeteta koji se koristi za ramenu stručnih i informacija na različitim nivoima, na, koli- 
ko god je to moguće, precizan, nedvosmislen i ekonomičan način (Pitch/ Draskau, 1985:72). Ovako shvaćen jezik struke predmet je teorijskih i praktičnih istraživanja još od šezdesetih godina XX veka. U našoj sredini, jezik struke, zastupljen više od pola veka u obrazovnom sistemu i na srednjoškolskom i na tercijarnom nivou, u poslednjih dvadestak godina intenzivno zaokuplja pažnju primenjenih lingvista i glotodidaktičara, u težnji da se rasvetli, jasno definiše i razgraniči od opšteg jezika. Poznato je da su se u prošlosti, a ponegde i danas, na pojedinim nefilološkim fakultetima, strani jezici tretirali kao da je reč o još jednom vidu filoloških studija. Nije bilo razlike u koncepciji nastave i metodološkim postupcima u odnosu na bilo koji drugi kurs opšteg stranog jezika. Neretko nastava se svodila na mehaničko i nekontekstualizovano uvođenje i memorisanje stručne terminologije i prevođenje stručnih tekstova koji često nisu bili autentični i reprezentativni za datu nauku. Uz to, mnogi fakulteti nisu prepoznali značaj i ulogu stranog jezika struke kao predmeta u okviru studijskih programa, te je on doživljavan kao sekundarni predmet, inferioran u odnosu na druge, čak nedostojan ozbiljnije pažnje istraživača, pa samim tim i jezičkih planera. Iako se specifičnostima učenja jezika za potrebe struke i nauke u poslednje dve decenije pridaje veća pažnja, a sama nastava u ovom periodu usklađuje sa savremenim tendencijama i sve više razlikuje od nastave opšteg jezika, pošto su uvažene potrebe i ciljevi onih koji strani jezik struke uče, istraživanja pokazuju da je nastava stranog jezika struke i dalje često ugrožena, da fond časova opada, a status predmeta varira, čak se dešava da negde prestaje da bude obavezni i prelazi u izborne predmete (Đorović i Mirić 2016: 41).

Nastava stranog jezika struke izvodi se na stručnim tekstovima koji služe za diseminaciju specijalističkih znanja. Baš kao što učenje jezika u funkciji struke ne može biti isto kao učenje jezika za opšte namene, tako i prevođenje u okviru nastave jezika struke ima svoje specifičnosti u odnosu na sticanje prevodilačke kompetencije na filološkim i prevodilačkim studijama. Glavna razlika leži u utilitarnom karakteru prevoda kao aktivnosti u okviru nastave jezika struke. Glavni cilj nije izrada besprekornog finalnog proizvoda - cljnog teksta koji sadržinski tačno, a stilski i estetski savršeno, dočarava polazni tekst. Prevod u okviru nastave jezika struke pre spada u kategoriju predagoških prevoda, jedne vrste pedagoškog sredstva kojim se podstiče razvijanje veštine razumevanja pročitanog. 
Umesto finalnog proizvoda fokus je na procesu prevođenja kao postepenog savladavanja teksta struke i njegovih disciplinarnih sadržaja izraženih posebnim jezičkim i diskursivnim sredstvima. Estetsko-stilska dimenzija prevoda bitna za literarno prevođenje, u drugom je planu u odnosu na što tačnije, preciznije, jasnije transponovanje značenja primarnih, a zatim i sekundarnih informacija stručnog, naučnog karatera koje izvorni tekst nosi. To je, uostalom, potpuno u skladu sa jezičkim potrebama ovako specifičnog tipa učenika stranog jezika - da uz pomoć poznavanja stranog jezika dođu do saznanja iz svoje oblasti studija ili profesionalnog angažovanja.

Na nižim nivoima učenja stranog jezika struke kojim ćemo se mi ovde baviti prevođenje se dakle usko vezuje za veštinu razumevanja pisanog teksta, odnosno razumevanja pročitanog. Reč je o procesu kroz koji se, s jedne strane, izvlači i konstruiše značenje kroz intereakciju s pisanim jezikom (Snow/Sweet, 2003). Osnovni cilj učenja na ovom nivou jeste osposobiti učenike za efikasno čitanje pisanih tekstova struke (za potrebe studija ili kasnije posla) i izvlačenje informacija i značenja iz njega na relativno brz i pouzdan način, i to s punim razumevanjem. Neka istraživanja ukazuju na to da korišćenje prevođenja kao jednog metodološkog postupka u razvijanju veštine razumevanja pospešuje učenje stranog jezika (Ringbom, 1987; Mahmoud: 2006). Takođe, interesovanje za prevođenje povećava se kako se u novije vreme naglašava značaj maternjeg jezika kao resursa za unapređivanje učenja jezika. Prevođenje tako može da se shvati kao aktivnost koja razvija tri veoma bitna kvaliteta koja imaju veliki značaj za učenje stranog jezika: tačnost, jasnost i fleksibilnost (Ross, 2000: 61). Na kraju, važno je istaći da se prevođenje u nastavi jezika struke ne izdvaja od čitanja, kao osnovne veštine u ovladavanju jezika strukom, već predstavlja svojevrstan metodološki pristup čitanju i razumevanju teksta struke.

\section{Od teksta do ključnih informacija: čitanje, prevođenje i razumevanje teksta struke}

U učenju i nastavi jezika struke veština čitanja ima centralno mesto: to je polazna receptivna veština usmerena na osposobljavanje stručnjaka i budućih stručnjaka da čitaju i koriste udžbeničku i stručnu literaturu, što je jedan od uslova da se uključe u akademski i profesionalni život naučne i diskursne zajednice kojoj po obrazovnom profilu pripadaju. Ono što ovu vrstu čitanja posebno izdvaja jeste postojanje naročite svrhe za koju se čita. Tekst 
struke čita se da bi se došlo do određenih informacija, podataka, saznanja vezanih za struku, da bi se razumele ideje i teorije opisane u tekstu, da bi se otkrivali i promišljali stavovi i mišljenja autora i, konačno, da bi se kroz sve već navedeno mogle preispitivati i sopstvene ideje i stavovi. Jednom rečju, učenik stranog jezika struke čita kako bi obavio neki zadatak (naučio nešto, došao do informacija, osposobio se da nešto izvede ili prikupio potreban materijal za diskusiju, pisanje, učenje i sl.). Tekst struke za njega je prenosnik relevantnih naučnih ili stručnih informacija. Otuda ne čudi što Nuttall naziva ovu kompetenciju content reading skill (Nuttall, 1996: 55).

Kao osnovne strategije i tehnike koje služe čitaocu da razume i kasnije koristi tekst struke navode se: predikcija, kritičko čitanje, dedukovanje nepoznatih reči, izvlačenje zaključaka, sumiranje, preispitivanje, letimično čitanje da bi se izvukla osnovna ideja autora (eng. skimming), čitanje na preskok da bi se izdvojila neka informacija iz teksta (eng. scanning), kao i azdvajanje relevantnih od irelevantnih, primarnih od sekundarnih informacija iz teksta (Jordan, 1997: 143). Za uspešno korišćenje pročitanog teksta struke neophodno je i razumevanje tekstualne organizacije i morfosintaksičkih i semantičkih aspekata teksta, uočavanje kohezije i koherencije teksta i zapažanje i korišćenje markera diskursa u tekstu. Sve ove strategije pomažu studentima da postanu takozvani metakognitivni čitaoci (McLaughlin/Allen, 2002:3), a to im dalje omogućava da pri čitanju i razumevanju tekstova struke svojim metakognitivnim sposobnostima nadomeste još uvek nedovoljno razvijene jezičke kompetencije na nižim nivoima učenja stranog jezika

Kada u učionici otpočne rad na tekstu, prirodno se javlja potreba da se i maternji jezik koristi kao pomoćno sredstvo, a onda prevođenje nije više skup veština koje treba savladati kako bi se izvorni tekst što vernije i bolje preneo u ciljni, već ono postaje resurs (Newmark,1988: 46). Prevođenje može da pospeši razumevanje jer uključuje pažljivo, koncentrisano čitanje, na nivou reči, rečenice i teksta i korišćenje gorenavedenih strategija koje su već savladane kad je reč o čitanju na maternjem jeziku. Ono razvija svest o jeziku kod učenika i pospešuje promišljanje teksta na svim nivoima, od leksičkog i morfo-sintaksičkog, do stilističkog i pragmatičkog.

U praksi, međutim, problem se javlja usled činjenice da se mnogi studenti ranije ili nisu sretali s prevodom uopšte, ili su, ukoliko i jesu, prevodili književne tekstove ili tekstove opšteg jezika na časovima stranih 
jezika u osnovnoj i srednjoj školi. Nisu svesni ni specifičnosti neknjiževnog teksta, ni različitih pristupa i strategija koje prevođenje za potrebe struke iziskuje. Nastavnik jezika struke ima stoga zadatak da ne otpočinje s prevođenjem bez pripreme, bez uvodnog časa posvećenog upravo tekstualnim i retoričkim specifičnostima tekstova struke i mogućim strategijama i tehnikama analiziranja, interpretiranja i transponovanja teksta, koje studenti dotle verovatno nisu imali prilike da upoznaju. Treba ih usmeriti na pravi način kako da se služe prevodom kao resursom za dostizanje cilja - a to je razumevanje teksta svoje struke. Valja im objasniti da je u ovom tipu prevođenja primarno tačno razumevanje ključnih informacija iz teksta i njihovo jasno transponovanje u ciljni tekst, a tek sekundaran estetsko-stilski aspekt (kojim se oni često opterećuju previše i stoga ne fokusiraju na tačnost prenetih ideja i informacija iz izvornog teksta). Iskustva u radu sa studentima pokazuju da se oni nekad nepotrebno zadržavaju na formalnim uobličavanjima pojedinih segmenata teksta, dok nedovoljno promišljaju pročitane sadržaje, nedovoljno koriste strategije povezivanja, zaključivanja i konstruisanja značenja. U pokušaju da tekst ne prevedu bukvalno dešava se da zanemare izvorni tekst, odstupe znatno od njega, dodajući proizvoljno značenja i tumačenja, ,prepravljajući ga“ po svom nahođenju, često nesvesni da ga time drastično menjaju. Oduzimaju mu celovitost, originalni informativni sadržaj i ugrožavaju ili potpuno narušavaju razumevanje pročitanog, što znači da stručni i naučni sadržaj teksta ne bi mogli, ili neće moći da pravilno i svrsishodno iskoriste za potrebe struke i nauke kojom se bave. Nažalost, problem preslobodnog i neutemeljenog prevoda stručnog teksta nije nepoznat našoj javnosti. Upravo kao posledica ovakvog slobodnog i nekritičkog prevođenja (koje neretko realizuju upravo stručnjaci dotičnih disciplina, ali očigledno nedovoljno upućeni u jezičke i diskursne specifičnosti struke), pojavljuju se u prevedenim tekstovima krupne, materijalne greške koje otežavaju ili onemogućavaju pravilno razumevanje, a time i korišćenje teksta za potrebe stručnjaka iz date oblasti.

\section{Cilj i metodologija istraživanja}

Osnovni cilj ovog istraživanja jeste ispitavanje efikasnosti prevođenja kao metodološkog postupka u nastavi stranog jezika struke za razvijanje veštine razumevanja teksta struke i osvešćivanje tekstualnih, pragmatičkih i diskursnih specifičnosti ovog tipa teksta. Koristeći se kvantitativno-kvali- 
tativnim pristupom i eksplorativno-deskriptivnim metodom, pokušali smo da sagledamo i istražimo 134 prevoda studenata druge godine Filozofskog fakulteta Univerziteta u Beogradu. Oni bez obzira da li su eventualno imali neko predznanje, uče italijanski jezik od početnog nivoa kao obavezan predmet, a s izlaznim nivoom receptivnog poznavanja jezika na nivou B1B1+Zajedničkog evropskog okvira za žive jezike, iako su zbog specifičnosti tekstova struke upoznali i ovladali i nekim elementima jezičkih znanja koji odgovaraju višim nivoima (poput pasiva, bezličnih konstrukcija, implicitnih infinitnih, participskih i gerundijskih struktura i sl.).

Kao instrument istraživanja korišćen je test prevoda teksta struke (iz oblasti filozofije, sociologije, istorije umetnosti, istorije, arheologije, andragogije, pedagogije, psihologije, klasičnih nauka, etnologije ili antropologije), uz mogućnost korišćenja italijansko-srpskog rečnika. Tekst koji se prevodi dužine je od 200 do 230 reči. Ova aktivnost inače je jedna od predispitnih obaveza pred izlazak na završni ispit na kraju druge godine učenja. Analizrani radovi čine prigodni uzorak studentskih prevoda rađenih u maju 2018. i i maju 2019. godine sa dve generacije studenata. Pre realizacije ovog istraživanja, studenti su tokom četvrtog semestra učenja bili najpre upoznati sa specifičnostima tekstova struke i načinom na koji ćemo koristiti prevod u nastavi, a zatim je na časovima a i kroz samostalan rad studenata ovaj zadatak uvežbavan na tekstovima različitih struka koje se izučavaju na fakultetu, budući da je grupa koja uči italijanski disciplinarno heterogena. $\mathrm{Na}$ testu prevoda, međutim, svaki student dobio je tekst vezan za svoju oblast studiranja. Tri osnovna parametra kojim smo se $u$ analizi vodili bila su: (a) zastupljenost ključnih informacija izvornog, italijanskog teksta u studentskim prevodima na srpski jezik i (b) stepen preciznosti u prenošenju ključnih informacija u procesu prevođenja i (c) stepen jasnosti u formulisanju ključnih ideja koje su studenti čitajući originalni tekst razumeli.

\section{Analiza rezultata i diskusija}

Za potrebe ovog istraživanja analizirano je 134 prevoda, a zastupljenost po studijskim grupama bila je sledeća: filozofija - 4, andragogija - 5, pedagogija -7, etnologija i antropologija - 10, klasične nauke 10 , sociologija 11 , arheologija - 16, istorija - 21, psihologija - 22, istorija umetnosti 27. Svaki student prevodio je tekst vezan za sopstvenu disciplinu. Prevodi studenata koji su činili uzorak ovog istraživanja najpre su detaljno analizi- 
rani u pogledu zastupljenosti ključnih informacija iz izvornog teksta u prevodu, kao i prema stepenu preciznosti i jasnosti u formulacijama ključnih elemenata izvornog teksta prenetih u ciljni tekst. Radi bolje preglednosti i lakše uporedivosti podataka, u svakom tekstu je prethodno izdvojeno po četiri ključne informacije koje su morale biti tačno prevedene u studentskim radovima kako bi se moglo smatrati da je student razumeo pravilno tekst. Kako bi se radovi lakše sagledali i kategorisali, odlučeno je da se za parametar (b), stepen preciznosti u prevodu i parameter (c), stepen jasnosti formulacije uspostavi skala od 1 do 3 , gde se 1 odnosi na najniži stepen a 3 na najviši stepen preciznosti odnosno jasnosti ustanovljenih u prevodu. Kao što je i bilo očekivano, kvalitet radova i uspešnost prevoda u velikoj meri varirao je kod ovako velikog broja ispitanika nejednakog nivoa vladanja italijanskim jezikom. Valja napomenuti da je dvadesetak studenata učilo prethodno italijanski jezik u nekom obliku, dok je velikoj većini druga godina i de facto druga godina učenja italijanskog uopšte. Takođe, nije nevažno da li ispitivani studenti vladaju dobro već nekim drugim stranim jezikom, da li su imali iskustva u prevođenju tekstova struke do sada kao i da li su i u kolikoj meri upoznati s tematikom teksta koji prevode te mogu da kao resurs koriste i svoja prethodna stručna znanja. Pošto je neizvodivo ujednačiti nivo znanja studenata koji uče italijanski u ovako heterogenoj grupi, pribegava se individualizaciji i diferencijaciji u dodeljivanju zadataka. To znači da su studenti koji su već učili italijanski pre dolaska na fakultet dobili da prevode nešto drugačije, jezički zahtevnije tekstove, u skladu sa pokazanim znanjem i nivoom. Ovaj princip rada primenjuje se i inače u nastavi i studenti su na njega navikli, svako napreduje od nivoa s kojim je ušao u učionicu.

Rezultati istraživanja pokazuju da je uspešnost prevoda, odnosno stepen razumevanja pisanog teksta struke koji se ovim metodološkim postupkom ispitivao, neujednačen, ali ipak kod više od polovine studenata zadovoljavajući. Kad je reč o zastupljenosti ključnih informacija izvornog, italijanskog teksta u studentskim prevodima na srpski jezik, rezultati pokazuju da se u radovima 42 studenata $(31,3 \%)$ nailazi na solidan, precizan i jasan prevod ključnih informacija, što pokazuje da su tekst razumeli (ovde ćemo ih nazvati grupom A). Delimično je odgovorilo na zadatak prevodeći dve ili tri od četiri ključne infomacije 36 studenata $(26,9 \%)$ koje smo svrstali u grupu B. Grupu C činilo je 38 studenta $(28,4 \%)$, koji su preneli samo jednu ključnu informaciju iz izvornog teksta u ciljni. Preostalih 18 
studenata $(13,4 \%)$ u čijim radovima je ili izostala bilo koja od ključnih informacija ili je preneta pogrešno, svrstano je u grupu D.

Uporednom analizom ovako kategorisanih radova uočili smo šta je ono što je moglo omesti pravilno razumevanje teksta struke kod studenata iz grupa B, C i D u odnosu na kolege iz grupe A. Pored boljeg poznavanja jezika koje je direktno uticalo na besprekornost prevoda kod jednog dela studenata iz grupe A, značajnu ulogu odigralo je i poznavanje konkretne teme teksta koji je prevođen. Iako su teme birane tako da pokrivaju gradivo već obrađivano na prve dve godine studija, nije svaki student podjednako usvojio i može da barata stručnim znanjima, a koja mogu biti ključna pomoć u prevođenju teksta struke kada su jezičke kompetencije nešto slabije. Studenti koji pokazuju bolji uspeh na studijama ujedno su bili i oni koji su uspešnije preveli tekst. Međutim, poznavanje teme nije uvek pozitivno uticalo na rad na prevodu. Naime, jedan od glavnih problema s kojim se u prevođenju za potrebe struke susrećemo jeste neutemeljeno dodavanje značenja (koja ne postoje u izvornom tekstu), semantička iskrivljenja elemenata teksta da bi se uklopili u mentalnu sliku o datoj temi koju student ima na osnovu svojih stručnih znanja i previdi kod leksema i sintagmi koje liče ili su lažni prijatelji s onima iz maternjeg jezika. Tada dolazi do arbitrarnog konstruisanja značenja nezavisno od polaznog teksta, od kojeg se prevod na taj način udaljava i obesmišljava. Ovaj fenomen javlja se i kod jezički kompetentnijih i kod onih manje kompetentnih studenata, verovatno kao posledica želje da se prethodno stečena specijalistička znanja iskoriste na pravi način i pripomognu u prevodu tamo gde je tekst možda jezički previše izazovan ili čak nesavladiv. Te pogreške idu od manjih odstupanja do ozbiljnih i pogubnih pogrešnih interpretacija originala, kao u primeru (1) koji sledi:

(1) Apprendimento umano presuppone una natura sociale specifica e un processo attraverso il quale i bambini si si inseriscono gradualmente nella vita intelettuale di coloro che li circondano. (Interpretazione Vygotskiana, 7)

Učenje čoveka predstavlja jednu socijalno specifičnu prirodu i jedan obrazovni proces_prelaska koji se detetu postepeno javlja tokom intelektualnog života i odrastanja u bojama koje ga okružuju. (PS 5 D) ${ }^{1}$

1 U primerima koje navodimo ovde dodaci su uokvireni, semantička iskrivljenja obeležana isprekidanom linijom, nedostajući elementi obeleženi znakom (?) a materijalne 
Iz navedenog primera jasno se uočava da student nije pažljivo pročitao tekst i proverio značenja i oblike u rečniku (npr. zamenicu coloro je shvatio kao boju colore), niti je savladao neke od osnovnih gramatičkih znanja (množina imenica i zamenica, razlika između prideva i priloga, prepoznavanje vrsta reči). Usled svega toga nije pravilno shvatio tekst, a kao strategiju snalaženja koristio je arbitrarno dodavanje elemenata struke u nadi da će se približiti tekstu originala. Ovakve greške obično se posle obavljenog testa prevoda eksplicitno obrađuju na časovima, kako bi se studentima još jednom skrenula pažnja na nedopustive propuste i previde koji ugrožavaju i urušavaju razumevanje teksta struke i njegovo adekvatno korišćenje izvan učionice stranog jezika.

Analiza grešaka osim toga jasno je pokazala da je određeni broj studenata izgubio iz vida globalni smisao teksta i u njemu jednu ili više ključnih informacija, stoga što je tekst prevodio linearno, reč po reč, ne uočavajući i koristeći elemente konteksta, kohezivna sredstva i diskursne obrasce i signale, već kalemeći srpske ekvivalente jedan na drugi po redu koji nalaže izvorni tekst. Na ovaj način lako je izgubiti se u tekstu pisanom na sintaksički kompleksnom i digresijama i umecima bogatom italijanskom jeziku humanističkih nauka. Iako se tokom nastave na ovo posebno upozoravaju studenti i uvežbava se prevođenje teksta na funkcionalan način (polazeći od traganja za ključnim segmentima koji će činiti kostur prevoda, kome se u sledećem navratu dodaju sekundarni elementi) i dalje mnogi studenti kada se suoče sa zadatkom prevođenja pribegavaju najpogubnijem načinu interakcije sa tekstom - dekodiranju teksta linearno i mehnički, reč po reč, bottom up tehnikom, te tako gube iz vida globalnu strukturu, makro-obrasce teksta i međusobne odnose elemenata unatar celine koju čini tekst. Tokom nastave mora se isticati da efikasan čitalac, a zatim i onaj ko tekst prevodi, treba da koristi simultano i bottom up i top down tehniku (Urquhart/Weir, 1998:220).

Nakon što je u radovima utvrđeno prisustvo nekih ili svih ključnih informacija pristupilo se pregledu teksta prevoda sa aspekta preciznosti u prenošenju tih segmenata teksta. Ovo smo smatrali neophodnim da bi se stekao bolji uvid u stepen razumevanja tih informacija kod studenata

greške podvučene. Oznaku na kraju prevoda čini sigla odeljenja s kojeg student doalazi (PS-psihologija, FS-filozofija, SO-sociologija itd.) broj rada, i grupa u koju je rad svrstan. Primeri na italijanskom preuzeti su iz korpusa tekstova koji se koriste u nastavi na Filozofskom fakultetu. 
iz grupa A, B i C, budući da samo prisustvo, odnosno pomen ključne informacije u prevodu, nije moralo značiti i precizno prenetu informaciju poteklu iz izvornog teksta. Od 42 studenta grupe A koja je prenela sve ključne informacije 30 studenata $(71,4 \%)$ prevelo ih je precizno, dok se u 12 radova $(28,6 \%)$ može uočiti neka vrsta nepreciznosti poput neadekvatnih terminoloških ili leksičkih izbora u datom kontekstu (npr. sponzor umesto mecena $\mathrm{u}$ tekstovima istorije umetnosti), pogrešno prenetih vlastitih i geografskih imena (npr. ital.Carlo IX prevedeno kao Karlo IX, umesto Šarl, budući da je reč o francuskom kralju; ital. Cologna, naziv grada Kelna, prevedeno kao kolonija). Napominjemo da je čak i u grupi A bilo primera izostanka pojedinih elemenata, uopštavanja, pojednostavljivanja, dodavanja, što ukazuje na potrebu da se o ovim strategijama snalaženja pri prevođenju govori i dalje na časovima vežbanja i rada na tekstu.

Kod grupa B i C procenat prevoda koji su bili nedovoljno precizni, uprkos tome što su se neke od ključnih informacija mogle naći u tekstu, bio je veći (B grupa - 38,8\%, C grupa - 47,4\%), kao u primeru (2). Ovakav trend mogao se očekivati: studenti koji su uspeli da u tekstu izdvoje i razumeju više ključnih informacija bili su u stanju da sa više preciznosti i tačnosti prenesu date informacije u ciljni tekst. Oni koji su uspeli da prenesu manje ključnih informacija često su to činili na manje precizan način.

(2) Episodi di pirateria sono riportati anche fin dai tempi più antichi della storia greca e romana, quando gli Etruschi erano conosciuti con l'epiteto greco Thyrrenoi, da cui deriva in nome del Mar Tirreno, e avevano fama di pirati efferati. (Pirati, corsari e schiavitù nel Mediterraneo, 1)

Priča o gusarenju potiče još iz (?) vremena grčke i rimske istorije kada su Etrurci nazivani grčkim imenom Tireni, (?) i kada su imali slavu (?). (AR 2 C)

Treći aspekt koji smo u ovom istraživanju uzeli u obzir jeste stepen jasnosti u formulisanju ključnih ideja koje su studenti čitajući originalni tekst uspeli da razumeju i prenesu u prevod. Za razliku od kriterijuma preciznosti prenete informacije koji spada u domen kognitivnih i metakognitivnih sposobnosti ispitivanih studenata i njihovog receptivnog znanja stranog jezika na određenom nivou, ovaj ugao posmatranja postignuća studenata tiče se više njihovih jezičkih i pragmatičko-tekstualnih znanja, i to ne samo 
stranog već i maternjeg jezika. Nivo postignuća u ovom pogledu nije na zavidnom nivou. Dve trećine analiziranih prevoda u ovom segmentu pokazuju neke nedostatke, dok je jedna trećina prevoda realizovana jezički i stilski jasno i na zadovoljavajući način. Ovde je važno istaći da jasno formulisan prevod ne znači da on mora biti napisan istančanim prečišćenim jezikom visokog registra i visoke estetske vrednosti, već da sadržaj mora biti jasno i valjano iskazan preciznim, akademsko-naučnim jezikom koji bi studenti na drugoj godini studija trebalo već dobro da poznaju, odnosno gramatički korektnim i leksičko-terminološki adekvatnim jezikom kojem bi uzor trebalo da budu udžbenici i stručna literatura poznata studentima na maternjem jeziku. Međutim, i većini radova mogli su se zapaziti manji, srednji ili veći propusti u ovom pogledu, kao što je slučaj u primeru (3).

(3) Un altro parametro stilistico del barocco è sicuramente la complessità. Nulla deve essere semplice, ma deve apparire come il frutto di un virtuosismo spinto agli estremi del possibile. (Arte barocca,1)

Još ima jedan drugi parametar stilistički baroka - to je sigurno kompleksnost. Ništa ne sme biti prosto, već mora se javiti kao neki plod virtuoznosti koji se gura do ekstema onog mogućeg. (IU $11 \mathrm{C}$ )

Ovako prevedene radove teško je vrednovati i često je potrebno dodatno razjašnjenje napisanog da bi nastavnik mogao da proceni da li je tekst shvaćen na pravi način. Postavlja se pitanje da li je ovakav nalaz vezan za nedovoljno jasan jezik i neprilagođen stil prevoda možda posledica činjenice da, usredsređeni na sadržaj i smisao teksta, studenti gotovo zapostave način na koji izražavaju ono što su razumeli, bilo zato što im je to poslednje na pameti, ili zato što jednostavno ne stignu da uobliče prevod jasno i nedvosmisleno nakon što su izvorni tekst pročitali i razumeli. Iz neformalne komunikacije sa studentima po obavljenom zadatku saznali smo da ima i jednog i drugog. Deo odgovornosti za ovakvo stanje ostaje i na nastavniku koji je možda premalo pažnje i vremena posvetio ovom aspektu prevođenja teksta struke, fokusirajući se prevashodno na što bolje razumevanje teksta i izvlaćenje primarnih informacija iz njega, a očekujući da jasno jezičko oblikovanje na maternjem jeziku neće biti problematično.

Na kraju, mora se napomenuti takođe da su u radovima uočene brojne pravopisne greške u pisanju na maternjem jeziku, što otvara potpuno 
novu, ali ne manje značajnu temu u vezi sa nastavom akademske pismenosti na tercijarnom nivou obrazovanja, koja međutim, nije bila predmet našeg istraživanja.

\section{Zaključna razmatranja}

Prevođenje u nastavi jezika struke, naročito na nižim nivoima, predstavlja jednu od mogućih tehnika rada na tekstu struke i provere razumevanja pročitanog. U ovoj vrsti obrazovnog konteksta, veština prevođenja razlikuje se u mnogome od one koja se vezuje za filološke ili prevodilačke studije. Osnovna razlika leži u instrumentalnosti prevoda koji nije svrha sam sebi, već sredstvo pomoću kojeg se dolazi do saznanja iz nauke koja se proučava. Ovo eksplorativno istraživanje predstavlja pokušaj da se ispitaju efekti korišćenja prevoda u nastavi stranog jezika struke i ukaže na eventualni smer unapređivanja ovog segmenta nastave, kako bi još više i adekvatnije mogao da pomogne našim studentima u učenju i radu na studijama. Ne sme se gubiti iz vida da će ono što nauče i iskuse na časovima stranog jezika u kontaktu s tekstovima jezika struke, biti osnov njihovog daljeg angažovanja na studijama, u struci i nauci, kad je reč o upotrebi i konsultovanju materijala na stranim jezicima.

$\mathrm{Na}$ osnovu rezultata prikazanih u ovom radu, može se zakjučiti da studentima može biti od koristi uvežbavanje veštine razumevanja posredstvom prevoda stručnog teksta na stranom jeziku, naročito ukoliko su prethodno eksplicitno upućeni i obučeni kako da prevode tekstove, na šta da obrate posebnu pažnju, kako da radu na tekstu pristupe organizovano, sistematično i kompetentno. Rezultati takođe pokazuju da su studetni bili uspešniji u globalnom razumevanju sadržaja struke u tekstovima koje su prevodili i izvlaćenju i razumevanju ključnih informacija iz teksta, nego u njihovom preciznom prenošenju i jasnoj formulaciji na maternjem jeziku.

Iako ovo istraživanje ne pretenduje na konačne odgovore i univerzalni recept smislenog i efikasnog korišćenja prevoda u nastavi jezika struke, nadamo se da će moći da posluži da osvetli jedan značajan aspekt ovako usmerene nastave stranih jezika i eventualno podstakne prepoznavanje novih istraživačkih problema u vezi s korišćenjem prevoda u nastavi jezika struke. Dobijeni podaci mogu poslužiti kao osnova za dalja, slična istraživanja, u drugačijim kontekstima i uslovima, ali koja bi sva pokušala da daju odgovor na pitanje zašto nam je prevod, u kom obliku i u koju svrhu i dalje potreban u nastavi stranih jezika. 


\section{LITERATURA}

Balboni, P. (1998). Tecniche didattiche per l'educazione lingusitica.Torino: UTET.

Bausch, K.R./Christ, H./Krumm, H.J. (1995). Handbuch Fremdsprachenunterricht. Tübingen: Francke.

Brown, D. H. (1972). Cognitive pruning and second language acquisition. Modern Language Journal, 56, 218-222.

Bugarski, R. (1997): Jezik u kontekstu. Beograd: Čigoja.

Butzkamm, W. (2002a). Psycholinguistik des Fremdsprachenunterrichts. Natürliche Künstlichkeit: Von der Muttersprache zur Fremdsprache. 3rd Edition. Tübingen: Francke.

Đorović, D. i Mirić, M. (2016). Višejezičnost u studijskim programima fakulteta nefilološke orijentacije univerziteta u Beogradu. Nasleđe, 13, (35), 29-43.

Freddi, G. (1999). Psicolinguistica, sociolinguistica, glottodidattica. Torino: UTET

Jordan, R.R. (1997). English for Academic Purposes A guide and resource book for teachers. Cambridge: Cambridge University Press.

Mahmoud, K. (2006). Translation and Foreign Language Reading Comprehension: A Neglected Didactic Procedure. English teaching Forum, 44(4), 2833.

McLaughlin, M./Allen, M.B. (2002). From Guided Comprehension: A Teaching Model for Grades 3-8. Newark, DE: International Reading Association.

Newmark. (1988). A Textbook of Translation/ Hamel Hempstead, England: Prentice Hall.

Nuttall, C. (1996). Teaching Reading Skills in a Foreign Language. London: Heinemann.

Pitch, H./J. Draskau (1985). Terminology. An introduction. University of Surrey: Guildford.

Ringbom, H. (1987). The Role of the First Language in Foreign Language Learning. Clevedon: Multilingual Matters.

Samardžić, M. (2009). Individualizacija u nastavi prevođenja. U : Vučo, J. (ur.) Individualizacija i diferencijacija u nastavi jezika i kniževnosti (pp. 262270). Nikšić: Univerzitet Crne Gore, Filozofski fakultet u Nikšiću.

Snow, C. E./Sweet, A. P. (2003). Reading for Comprehension. In Sweet, A.P./ Snow, C.E. $\quad$ (eds.), Rethinking Reading Comprehension. New York: The Guilford Press. 
Urquhart, S/Weir, C. (1998). Reading in a Second Language: Process, Product and Practice, London: Longman.

Vučo, J. (2009). Kako se učio jezik. Pogled u istoriju glotodidaktike od prapočetaka do Drugog svetskog rata. Beograd: Filološki fakultet.

\section{Danijela S. Đorović}

THE ROLE OF TRANSLATION IN LSP TEACHING

\section{Summary}

Translation in LSP differs greatly from translation seen as one of the language skills taught within philology or translation studies. Just as LSP teaching regards foreign language competence as a means of acquiring subject-specific knowledge and skills, so translation in LSP is primarily oriented towards extracting the main ideas and key information from the specialized texts. In this paper an attempt has been made to review the role of translation in LSP teaching as a specific methodological procedure used to develop students' specialized reading comprehension at lower levels of language competence.

For the purpose of this exploratory study, 134 written translations of specialized, social sciences and humanities texts have been analyzed. The students whose translations were subjected to the analysis are second-year students of the Faculty of Philosophy, University of Belgrade who study Italian for Specific Purposes as a compulsory biannual course within their curricula. The results obtained indicate that subject-oriented translation, previously introduced and practiced in the classroom, may have positive effects on global and detailed reading comprehension of specialized texts, on raising language and discourse awareness, as well as on the development of metacognitive and cognitive skills useful for tackling lingustically complex subject-specific texts.

Key words: translation, LSP, university language teaching, reading comprehension, Italian language 